\title{
МОНІТОРИНГ ТА ОЦІНКА ЕФЕКТИВНОСТІ БІЗНЕС-ПРОЦЕСІВ ГРОМАДИ
}

\author{
Біленко В. О. к. е. н., ст. викл. \\ Украӥна, м. Запоріжжя, Запорізький національний університет
}

DOI: https://doi.org/10.31435/rsglobal_ijite/01062018/5655

\section{ARTICLE INFO}

Received 10 April 2018

Accepted 08 May 2018

Published 01 June 2018

\section{KEYWORDS}

Community,

business process,

economic efficiency,

monitoring system,

united territorial community

\begin{abstract}
The essence of business process management theory is investigated. It is noted that the effective functioning of the organization in modern conditions is largely determined by the formalization of interacting business processes performed in the organization. The analysis of the business process classification, existing business process models, the estimation of economic efficiency and the analysis of existing systems of business process monitoring are presented. The features of economic-mathematical models of business process reengineering are noted, as well as an example of optimization of the business process of supporting the users of the united territorial community.
\end{abstract}

(C) 2018 The Author.

Вступ. Інтенсивний розвиток ринкових відносин потребує від організацій пошуку та використання нових ефективних інструментів конкурентної боротьби, у першу чергу, таких, які дозволяють більш повно задовольняти вимоги споживачів та спрямовані на підвищення якості послуг. Одним 3 таких підходів $\epsilon$ управління бізнес-процесами - цілеспрямована скоординована діяльність (що включає технологічні та управлінські аспекти) щодо досягнення високих результатів бізнес-процесів шляхом ефективного використання ресурсів та 3 урахуванням узгодження процесів функціонування організації 3 вимогами зовнішніх споживачів. Управління бізнес-процесами є циклічною безперервною діяльністю, що не може виконуватись фрагментарно. 3 цих причин значна увага приділяється їх поліпшенню.

Аналіз останніх досліджень та публікацій. Проблемам вибору моделі та визначення економічної ефективності бізнес-процесів приділяли увагу зарубіжні та вітчизняні вченідослідники, серед яких: М. Мескон, Ф. Хедоурі, М. Портер, Хаммер М. Г. Ципес, А. Товб, Х. Біннер та К. С. Безггін, В. А. Івлєв, В. Г. Сліфьоров та В. В. Рєпін.

Не дивлячись на велику зацікавленість вчених та дослідників до питання визначення сутності та удосконалення бізнес-процесів, комплексний підхід до зазначених питань у науковій літературі відсутній. Для вирішення поставлених питань потрібно комплексно розглянути методи удосконалення бізнес-процесів, а також зазначити сутність та особливості бізнес-процесів такої особливої економічної структури, як об'єднаної територіальної громади.

Мета цього дослідження полягає в необхідності теоретичного обгрунтування особливостей управління бізнес-процесами громади та розробленні рекомендацій щодо використання громадами України сучасних методик та оцінок ефективності управління бізнес-процесами.

Результати дослідження. Всі процеси в будь-якій економічній системи можна розподілити на дві складові - ті, що додають цінність продукту/послугам, i ті, що не збільшують його споживчу вартість. Критерій збільшення складової додання цінності процесу може використовуватися як основа для оптимізації бізнес-процесів компанії. Для оцінки бізнеспроцесів, що додають економічну цінність для окремого бізнес-процесу, цю додану вартість можна виразити у вигляді питомого показника, таким чином визначивши ефективність процесу шляхом співвіднесення витрат до отриманої додаткової вартості.

Висока ефективність діяльності організації в цілому може мати місце тільки при достатній ефективності окремих іiї бізнес-процесів та, відповідно, осіб, що їх виконують.

Одним 3 найбільш важливих оперативних показників та критеріїв оцінки будь-якої економічної системи повинен бути показник тривалості циклу завершення процесу. Загальна тривалість циклу - це та кількість часу, яке проходить з моменту початку виконання задачі до 
моменту їх повного виконання. Показник тривалості робочого циклу надзвичайно важливий не тільки $з$ точку зору розрахунку собівартості, але й з точки зору важливості для клієнта. Наскільки «оптимальним» $є$ показник тривалості циклу в кінці кінців може оцінити тільки клієнт - він залишиться або задоволеним цим показником або ні.

3 точки зору фінансової оцінки важливими будуть показники вартості процесу, тобто затрат на здійснення одноразового циклу цього процесу, а також активи, що використовуються для його здійснення.

При вимірюванні ефективності необхідно окремо розглядати складові самого процесу. Процес можна розділити на вхідні параметри, дії, вихідні парламенти, результати. Так, коли мова йде про результати процесу, потрібно визначити наступні критерії ефективності процесу:

- чи призводить процес до бажаного результату;

- наскільки результат процесу задовольняє вимоги споживача. вартості.

При цьому результат процесу може бути виміряний в одиницях якості, кількості, часу, громади.

Розглянемо більш детально, яким чином оцінюється ефективність бізнес-процесів IT

Для оцінки ефективності виділяють 5 ключових галузей управління IT:

- відповідність стратегії - робить акцент на зв'язку між планами бізнесу та IT, а також на відповідність ІТ та бізнес-операції;

- корисність - являє собою реалізацію вартісної пропозиції, контроль за тим, щоб IT забезпечували переваги, визначені стратегією, зосередження на оптимізації затрат та підтвердження справжньої цінності IT;

- управління ресурсами присвячено питанням, пов'язаним з управлінням критичними IT-ресурсами, а саме, оптимізацією інвестицій та належним керівництвом програмами, інформацією, інфраструктурою та персоналом. Ключові питання стосуються оптимізації знань та інфраструктури.

- управління ризиками потребує поінформованості вищого керівництва в галузі ризиків, чіткого розуміння корпоративного підходу по відношенню до них, відповідності вимогам прозорості по відношенню до істотних ризиків, включення функцій управління ризиками в практику організації

- оцінка ефективності являє собою контроль за реалізацією стратегії, результатами проектів, використанням ресурсів, ефективністю процесів та сервісним обслуговуванням. Для цього застосовуються, зокрема системи збалансованих показників, які перетворюють стратегію в послідовність дій, результати яких вимірюються іншими, порівняно з бухгалтерським обліком, методами.

Для окремо взятого процесу галузь може бути пріоритетною, другорядною або незначущою. Так, в процесі «Розробка стратегічного плану розвитку IT» значущими $€$ параметри «Результативність» та «Ефективність». При цьому перший критерій являється пріоритетним, а другий - другорядним.

Іншим фактором для оцінки моделі зрілості являються показники результативності (KGI) та показники ефективності (KPI).

Показник результативності говорить про те, чи досягнуті певні цілі. Ці показники можуть бути виміряні тільки після здійснення факту і тому називаються «індикаторами затримки».

Показники ефективності говорять про те, чи можливе взагалі досягнення цілі. Ці показники можуть бути виміряні до отримання результату, і тому називаються «індикаторами випередження».

Показники KPI та KGI можна розділити на три рівня: рівень бізнес-цілей, рівень ITпроцесу та рівень дій. На першому рівні показники ефективності IT визначають, що являється вкладом IT в досягнення бізнесу-цілей і як це виміряти. На другому рівні показники ефективності IT-процесу демонструють, що являється вкладом IT-процесу в досягнення ITцілей і як це вимірювати. На третьому рівні показник ефективності окремих видів діяльності визначає, що має відбутися всередині IT-процесу для досягнення необхідної ефективності та як це виміряти. Показники для всіх рівнів та процесів наведені в таблиці 1. 
Таблиця 1. Значення оцінки при вимірюванні коефіцієнта в балах від 0 до 5

\begin{tabular}{|c|c|c|}
\hline 0 & немає даних & Неіснуючий \\
\hline 1 & дуже низька & Початковий \\
\hline 2 & низька & Інтуїтивний \\
\hline 3 & середня & Визначений \\
\hline 4 & вище середнього & Керований та вимірюваний \\
\hline 5 & висока & Оптимізований \\
\hline
\end{tabular}

Для оцінки обраних процесів використовуються критерії ефективності та результативності. за способами розрахунку критерії можна згрупувати у декілька типів:

- Tun "Частка" (\%). Частка являе собою відношення кількості атрибуту, що вимірюється та вказаний у найменуванні критерію,та загальної кількості даної властивості. Атрибутами можуть виступати інвестиції, гроші, робочі години або дні, кількість співробітників, зацікавлені сторони, посади, проекти, простої тощо. Розраховане значення помножується на сто, таким чином отримуємо процентний вираз показника.

- Tun "Число" (шт., грошові одиниці, години/дні/тижні). Кількісний показник, який визначається простим підрахуванням необхідного атрибуту. Наприклад, число звернень, число підрозділів. Іноді такі показники також можуть бути виміряні у відсотках за принципом вирахування "часток".

- Tun "Оиінка". Це показники, для яких одиницею виміру виступають бали від 0 до 5. принцип підрахунку таких показників взятий по аналогії з моделями зрілості.

Бажані результати (KGI) являють собою короткі рекомендації або максимальне значення показників результативності. Дані рекомендації також можна розподілити за типами:

- Tun "Оптимізація". Даний критерій означає, що не існує числового або ідеально скінченого результату для оцінки показника. Завданням управління є виведення значення цього показника на оптимальний рівень, що відповідає стратегічним і тактичним цілям організації.

- Tun "Максимізація". Вимірюваний показник володіє скінченним значенням, але $\epsilon$ недосяжним через суб'єктивні та об'єктивні причини, тому бажаним результатом в оцінці такого показника $€$ максимізація (збільшення) значення показника. Прикладом такого показника може слугувати "Частка членів Ради директорів, що пройшли навчання управління IT". Об'єктивно зрозуміло, що досягти 100-відсоткового результату даного показника практично неможливо, а також не є настільки необхідним. але користь від збільшення числа грамотних управлінців IT в Раді директорів неможливо не враховувати.

- Tun "Мінімізація". Вимірюваний показник володіє скінченним значенням, але являється недосяжним через суб'єктивні та об'єктивні причини, тому бажаним результатом в оцінці такого показника є мінімізація (зменшення) значення показника. Наприклад, показник "Тимчасова затримка між виявленням потреби в навчанні та наданні навчання". Правильно припустити, що неможливо зробити даний показник рівним нулю, але прагнення до зменшення витрат показника являється пріоритетним в управлінні IT.

- Tun "100\%" та mun "0\%". Максимально можливе значення та мінімально можливе значення показника.

Вимірявши показники, можливо співвіднести їх 3 максимальними значеннями та визначити до якого рівня зрілості можна віднести процес в цілому.

Однією зі складових процесного підходу $є$ оцінка результатів бізнес-процесів та їх ефективність. В методичних матеріалах 3 організації процесно-орієнтованого управління під результатами процесу розуміється здатність процесу досягати поставлених цілей, а під ефективністю - зв'язок між досягнутими результатами та використаними ресурсами.

До показників прибутковості належать: рентабельність реалізованої продукції (відношення валового або чистого прибутку до собівартості реалізованої продукції), рентабельність капіталу (відношення валового або чистого прибутку до середньорічної вартості майна) і т. п.;

до показників оборотності - коефіцієнт загальної оборотності капіталу (відношення обсягу реалізації (продажу) до середньорічної вартості майна), коефіцієнт оборотності (відношення кількості календарних днів у році (365 днів) до кількості оборотів) і т. п.;

до показників залучення позикових коштів - коефіцієнт співвідношення позикових і власних коштів, коефіцієнт довгострокових залучених позикових коштів. 
до показників фінансової стійкості - коефіцієнт фінансової стійкості (відношення власних і довгострокових позикових коштів до середньорічної вартості майна), дохід на довгостроковий кредит, дохід з обороту;

до показників платоспроможності - відношення сумарної заборгованості до сумарних активів, коефіцієнт покриття відсотка за кредитами ;

до показників ліквідності оборотних активів - коефіцієнт абсолютної ліквідності, проміжні коефіцієнти ліквідності, коефіцієнт маневреності.

На основі аналізу перерахованих показників визначаються майбутні результати господарської діяльності підприємства: терміни окупності інвестицій, рентабельність продукції і виробництва, рівень прибутку, достатній для сплати податків, дивідендів, кредиту та створення різних фондів.

Основні формули для розрахунку перелічених показників наведені в таблиці 2.

Таблиця 2. Формули розрахунку показників економічної ефективності

\begin{tabular}{|c|c|c|}
\hline$E_{p}$ & $=$ & $\left(C_{1} / Q_{1}-C_{2} / Q_{2}\right) /\left(K B_{2} / Q_{2}-K B_{1} / Q_{1}\right)$ \\
\hline$T_{p}$ & $=$ & $1 / E_{p}$ \\
\hline$T_{p}$ & $=$ & $K B / \Pi P_{\text {реал }}$ \\
\hline $3_{n p i}$ & $=$ & $C_{i}+K B_{i} \cdot R_{H}$ \\
\hline$\vartheta_{t}$ & $=$ & $P_{t}-3_{t}$ \\
\hline$Э_{\text {инт }}$ & $=$ & $\sum_{t=1}^{T}\left[\ni_{t} /(1+E)^{t}\right]$ \\
\hline ЧДД & $=$ & $Э_{\text {инт }}$ \\
\hline ЧДД & $=$ & $P_{T}-3_{T}$ \\
\hline ЧДД & $=$ & $Э_{\partial}-K_{\partial}$ \\
\hline ИД & $=$ & $P_{T} / 3_{T}$ \\
\hline ИД & $=$ & ЧДД / KB \\
\hline$K B_{63}$ & $=$ & $\sum_{i=1}^{t} K B_{i} \cdot(1+E)^{T-i}$ \\
\hline$K B_{63}$ & $=$ & $\sum_{i=1}^{t} K B_{i} \cdot[1-Д \cdot(i-1)] \cdot(1+E)^{T-i}$ \\
\hline Д & $=$ & $K B / t$ \\
\hline$K B_{n p}$ & $=$ & $\sum_{i=1}^{t} K B_{i} \cdot(1+E)^{T-i}$ \\
\hline$K B_{\text {nped }}^{6 p}$ & $=$ & $Э_{\text {год }} / R_{H}$ \\
\hline$\Delta K B_{3}$ & $=$ & $\bigsqcup_{H}{ }^{\prime}-\bigsqcup_{n e p}-\bigsqcup_{л}$ \\
\hline $3_{T}$ & $=$ & $\sum_{t=1}^{T}\left[3_{t} /(1+E)^{t}\right]$ \\
\hline$P_{T}$ & $=$ & $\sum_{t=1}^{T}\left[P_{t} /(1+E)^{t}\right]$ \\
\hline$\bigsqcup_{H}{ }^{\prime}$ & $=$ & $\bigsqcup_{H}+Ц_{o c m}-\bigsqcup_{л}$ \\
\hline$\bigsqcup_{o c m}$ & $=$ & $\bigsqcup_{n} \cdot\left(1-H_{a} \cdot T_{\ni к с}\right)$ \\
\hline$\bigsqcup_{\text {nep }}$ & $=$ & $\bigsqcup_{n} \cdot H_{a} \cdot T_{\text {экс }}$ \\
\hline
\end{tabular}

де:

$\bigsqcup_{n}$ - первісна ціна замінної техніки;

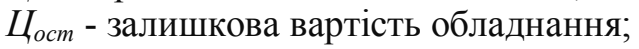

$\bigsqcup_{л}$ - ліквідаційна вартість обладнання;

$Ц_{\text {nер }}$ - перенесена вартість обладнання;

$Ц_{н}$ - нова ціна устаткування;

$\bigsqcup_{H}{ }^{\prime}$ - нова скоректована ціна устаткування з урахуванням заміни;

$K B_{i}$ - капітальні вкладення по і-му варіанту;

$K_{\partial}$ - дисконтовані капітальні вкладення; 
$K B_{63}$ - капітальні вкладення повернуті (сума повернення за кредит);

$K B_{n p}$ - наведені капітальні вкладення;

$\Delta K B_{3}$ - додаткова величина капітальних вкладень на заміну обладнання;

$K B_{n p e d}^{\text {sp }}$ - верхня межа допустимих капітальних вкладень;

ЧДД - чистий дисконтований дохід;

ИД - індекс прибутковості;

$E$ - норма дисконту, ставка за кредит;

$E_{H}$ - нормативний коефіцієнт ефективності капітальних вкладень;

$E_{p}$ - розрахунковий коефіцієнт ефективності капітальних вкладень;

$Э_{t}$ - ефект, що досягається на $t$-му році розрахунку;

$Э_{\text {инт }}$ - інтегральний ефект від здійснення капітальних вкладень;

$Э_{\partial}$ - дисконтований ефект;

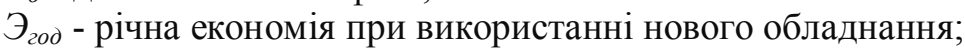

$H_{a}$ - норма амортизації;

$i$ - рік здійснення капітальних вкладень;

Д - частка капітальних вкладень, що припадають на один рік;

$t$ - період кредиту в роках;

$T$ - період здійснення капітальних витрат або рік після повернення кредиту : $\mathrm{T}=\mathrm{t}+1$;

$T_{H}$ - нормативний термін окупності капітальних вкладень;

$T_{p}$ - розрахунковий термін окупності капітальних вкладень;

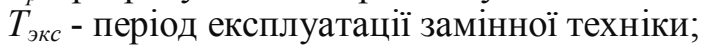

$R_{H}$ - нормативна рентабельність підприємства;

$R_{p}$ - розрахункова рентабельність підприємства;

$3_{t}$ - витрати, вироблені в $\mathrm{t}$-му році;

$3_{T}$ - витрати за весь термін Т;

$3_{n p i}$ - наведені витрати по і-му варіанту;

$P_{t}$ - результати, досягнуті в $\mathrm{t}$-му році;

$P_{T}$ - результати за весь термін Т.

Вибір ключових показників бізнес-процесу - достатньо відповідальний та неоднозначний процес. Це стає особливо очевидним, коли відбувається визначення нефінансових показників. Фінансові показники в компанії відстежуються постійно, а ось визначення нефінансових показників, тим більше, на першому етапі, достатньо складно через їх неоднозначність. Так, якщо в якості основної цілі компанією декларується збільшення чистого прибутку від реалізації, то в якості можливих шляхів ії досягнення можуть виступати підвищення лояльності зі сторони існуючих клієнтів та збільшення кількості нових споживачів. В свою чергу, такі наслідки, як підвищення лояльності пов'язані з оптимізацією якості послуг, збільшенням швидкості обробки заяв на послуги, підвищенням якості сервісного обслуговування (показники, що мають відображення в проекції внутрішніх бізнес-процесів).

Управління процесом 3 боку власника будь-якого рангу і рівня пов'язано насамперед 3 обробкою й аналізом великої кількості інформації. Безперервне поліпшення передбачає поступовий рух у напрямку високої якості роботи. При просуванні цим шляхом необхідні постійні коригування цілей і методів їх досягнення. Одним з найглибших помилок радянського стилю керівництва було трактування знаменитої ленінської фрази про «... головну ланку, схопивши за яку можна витягнути весь ланцюг ». Трактування полягала у спрощеному підході до будь-якої проблеми : потрібно знайти ту ручку, повернувши яку можна відразу досягти успіху. Насправді для його досягнення потрібно не крутити одну ручку, а регулювати кілька десятків «ручок» - параметрів процесу, вимірюючи результати і домагаючись їх оптимального поєднання. Зростаючий інформаційний потік i розвиток програмних засобів роблять доступним проведення аналізу складної i багатофакторної обстановки, утримати яку в голові не може жодна людина.

Централізована система моніторингу - це інтеграційне рішення, що дозволяє контролювати доступність та якість виконання бізнес-процесів та систем компанії на основі єдиного поля подій та даних.

Процес управління моніторингом - набір дій та процедур, спрямованих на забезпечення актуальності та несуперечливості системи моніторингу. Він включає в себе такі процеси, як:

- стандарт моніторингу;

- регламент підключення до моніторингу стандартних елементів IT-інфраструктури;

- регламент підключення до моніторингу нових систем, сервісів та процесів; 
- регламент розробки метрик та модулів моніторингу;

- регламент використання системи моніторингу;

- регламент підтримки системи моніторингу;

- регламент автоматичного заведення інцидентів.

Сучасні системи моніторингу повинні оцінювати не тільки роботу програмного забезпечення в цілому, з усіма його компонентами та їх взаємозв'язками, але й наскільки комфортно користувачу працювати 3 системою (час реагування). Тому система моніторингу повинна відповідати наступним ключовим питанням та завданням:

- як працює той чи інший компонент IT-системи с точки зору користувача; інфраструктурі;

- яка поточна активність користувачів при роботі 3 системами присутня в IT-

- як поточна робота 3 точки зору користувача відображається в заданих сервісних угодах (SLA);

- якщо (SLA) не дотримується, то які компоненти на це впливають;

- які затримки, на яких етапах роботи користувачів найбільше впливають на роботу програмного забезпечення і з цим вони пов'язані;

- які системи зачіпають собою те чи інше розподілене програмне забезпечення або бізнес-сервіс;

- як реально виглядає бізнес-процес, згідно якого повинні працювати IT-системи 3 прив'язкою до ІТ-компонентів;

- як один формалізований бізнес-процес впливає на інший та чому;

- який шлях проходять транзакції користувача від його клієнта через всі інші компоненти та назад;

- якою $є$ статистика параметрів роботи бізнес-процесів, яким $є$ його якість;

- чи дійсно поточна проблема в бізнес-процесі пов'язана зі збоєм в IT або це пов'язано 3 комунікаціями між бізнес-підрозділами;

- що відбувається всередині Java,.Net та всередині серверів програмного забезпечення;

- що уповільнює роботу бізнес-додатку, які строки коду або запити призводять до такого уповільнення;

Система моніторингу бізнес-процесів може бути корисною на всіх рівнях управління організацією (таблиця 3).

Таблиця 3. Результат впровадження системи моніторингу для користувачів

\begin{tabular}{|c|c|}
\hline $\begin{array}{l}\text { Підрозділи компанії, } \\
\text { користувачі }\end{array}$ & Що отримують \\
\hline $\begin{array}{l}\text { Топ-менеджмент } \\
\text { громади }\end{array}$ & $\begin{array}{l}\text { - доступність та якість виконання бізнес-процесів та послуг компанії; } \\
\text { - візуалізація дотримання SLA підрозділами компанії; } \\
\text { - основні показники бізнес-процесів компанії в режимі реального часу, КPI; } \\
\text { - доступність та якість основних послуг компанії }\end{array}$ \\
\hline Бізнес-підрозділи & $\begin{array}{l}\text { - візуальне подання бізнес-процесів підрозділу та суміжних бізнес-процесів } \\
\text { інших підрозділів; } \\
\text { - звітність доступності систем та модулів, що забезпечують бізнес-процеси } \\
\text { підрозділу; } \\
\text { - метрики та КРІ бізнес-процесів компанії. }\end{array}$ \\
\hline $\begin{array}{l}\text { Керівництво IT- } \\
\text { підрозділів }\end{array}$ & $\begin{array}{l}\text { - доступність та рівень сервісу за всіма IT-системами та процесами; } \\
\text { - візуалізація дотримання SLA IT-підрозділами компанії }\end{array}$ \\
\hline $\begin{array}{l}\text { Співробітники } \\
\text { служби Service Desk, } \\
\text { адміністратори IT- } \\
\text { систем }\end{array}$ & $\begin{array}{l}\text { - візуалізація дотримання SLA службою Service Desk; } \\
\text { - дані метрик доступності IT-систем, серверів та елементів інфраструктури } \\
\text { компанії; } \\
\text { - візуальне подання впливу збоїв IT-систем на бізнес-процеси в компанії; } \\
\text { - стан збоїв та інцидентів в різних розрізах (по системах, пріоритету, } \\
\text { регіонам тощо); } \\
\text { - завантаження серверів та додатків в режимі реального часу у зручному для } \\
\text { кожного адміністратора вигляді; } \\
\text { - статична звітність завантаження серверів та додатків. }\end{array}$ \\
\hline
\end{tabular}


Рішення моніторингу бізнес-процесів дозволяє:

- встановити прозорість між роботою IT та вимогами бізнес-підрозділів;

- відображати дані роботи бізнес-процесів, бізнес-додатків та розподілених бізнесдодатків на мові, зрозумілій бізнесу (в грошах, простоях тощо);

- забезпечити мінімальні відхилення в роботі систем від заданих характеристик продуктивності та доступності;

- IT може обгрунтувати перед бізнесом потреби в оновленнях апаратного i програмного забезпечення;

- наочно надавати споживачам та постачальникам інформацію про їх бізнес-процеси та бізнес-сервіси;

- управляти рівнем послуг.

Однією 3 невід'ємних частин загальної системи управління бізнес-процесами та організацією в цілому є моніторинг бізнес-активностей (Business Activity Monitoring, BAM).

Наразі BAM (Business Activity Monitoring) визначається як технологія, що діє в режимі реального часу та забезпечує регулярне інформування, поточний аналіз та вироблення аварійних сигналів. ВАМ підтримує все це, базуючись на відомостях від "датчиків", які в даному випадку називаються ключовими індикаторами виробництва. Технологічна можливість створення ВАМ з'явилася у зв'язку з розвитком програмного забезпечення проміжного шару, заснованого на обміні повідомленнями, а також інтеграційних брокерів та архітектур, орієнтованих на сервіси.

ВАМ перетворюється в одну 3 чотирьох основних рушійних сил, що сприяють припливу інвестицій в IT. Для створення ефективної системи ВАМ знадобиться створити комбінацію даних, що надходять в режимі реального часу, та накопичених (історичних) відомостях. Рішення цього завдання потребує інтеграції різнорідної інформації, джерелами якої можуть бути сховища даних (data warehouse), сховища операційних відомостей (operational data store) та бази даних програмного забезпечення (application database).

Моніторинг активності бізнесу можна розглядати як наступний еволюційний етап в розвитку засобів бізнес-аналітики, що збільшує оперативність цієї технології. тому й технологію ВАМ можна представити майже так, як бізнес-аналітику, але 3 тією суттєвою відмінністю, що тут з'являється новий елемент - сховище даних реального часу (Real-Time Store, RTS). Воно може охоплювати події, які відбуваються в апаратному забезпеченні та програмному забезпеченні, а також інші дані, безпосередньо пов'язані з проходженням бізнеспроцесів. Сервер ВАМ зберігає ці дані в пам'яті та робить їх доступними для аналітичних інструментів та засобів підготовки звітів.

Для оцінки «масштабу» моніторингу, необхідно класифікувати події, їх джерела та засоби роботи 3 ними:

- Одиничні важливі події. Такого роду подій (наприклад, аварійні сигнали) дійсно можуть надходити від визначених датчиків KPI або у формі якогось документу. Для їх обробки може бути підготовлений спеціалізований інструмент, що діятиме за заздалегідь визначеним планам та правилам.

- Обчислювані подї, що надходять в режимі реального часу. Це означає, що є детерміноване джерело даних, оснащене датчиком КPI, і що дані можуть бути змінені, оброблені і без зайвих проблем надані в графічній формі.

- Потокові випадкові події. Відомості про такі події надходять в режимі реального часу, причому їх номенклатура наперед відома, але час надходження не визначений. При їх аналізі необхідно встановити відповідність між подією та причиною їх виникнення.

- Складні події, що припускають існування відомого образу. Потік одиничних подій може складатися в таку складну подію, образ якої завчасно відомий. Образ складної події складається не тільки 3 простих подій, але й зі зв'язків між ними.

- Формування образів подій. Вищий рівень роботи з подіями полягає в тому, щоб у випадковому потоці повідомлень вбачати факти виникнення нових подій. Поки що це властиве лише людині, в чому власне і полягає мистецтво управління.

Серед усіх категорій лише перші дві мають повну аналогію з сигналами в технічних системах. Це ніскільки не зменшує переваг таких систем, вони можуть бути надзвичайно корисними, але необхідно розуміти, що вони охоплюватимуть лише частину діяльності організації.

До складу діяльності з управління бізнес-процесами входить також ВРM (Business Process Monitoring). 3 однієї сторони, ВРМ можна розглядати як філософію менеджменту, що дозволяє 
сфокусувати увагу на процесах та продуктивності виконання процесів. 3 іншої (при переході на більш низький рівень, наближений до IT) - набір методів та засобів для більш ефективної організації бізнес-процесів. Таким чином, ВРМ - це дисципліна, яка дозволяє проектувати та впроваджувати процеси, а також маніпулювати ними шляхом оркестрування системних сервісів. Порівнюючи ВРМ та ВАМ можна сказати, наступне: характерна риса першої технології можливість управління в кожен момент окремо взятим процесом за заздалегідь визначеними правилами, а ВАМ дозволяє спостерігати за виконанням процесів, контролювати їх виконання, дотримання правил та передавати отримані відомості персоналу. Наявність ВРМ не являється обов'язковою вимогою для впровадження ВАМ, але цю технологію можна розглядати як наступний крок по відношенню до ВРМ. В свою чергу, ВРМ можна розглядати одночасно як концепцію менеджменту і як підтримуючі цю концепцію технології.

Висновки. Моделювання бізнес-процесів дозволяє не тільки визначити, як громада працює в цілому, як взаємодіє із зовнішніми організаціями, замовниками й постачальниками, але і як організована діяльність на кожному робочому місці. Моделювання бізнес-процесів - це ефективний засіб пошуку шляхів оптимізації діяльності об'єднаної територіальної громади, засіб прогнозування й мінімізації ризиків, що виникають на різних етапах реорганізації організації. Цей метод дозволяє дати вартісну оцінку кожному окремому процесу й всім бізнеспроцесам організації в сукупності.

Аналіз ефективності бізнесу-процесу - аналіз результатів виконання бізнес - процесу й/або параметрів, що характеризують виконання процесу в динаміку, і порівняння отриманих показників з витратами (тимчасовими, фінансовими, матеріальними, людськими), необхідними для здійснення даного процесу, i/або цільовими показниками ефективності процесу. Моніторинг $\epsilon$ суттєвим елементом механізму вдосконалення керування бізнес-процесами із складною ієрархічною структурою, що потребує участі всіх ланок керівництва організації. Його впровадження дозволяе сформувати комплексну систему інформаційних потоків 3 удосконалення бізнес-процесів організації, своєчасно відслідковувати відхилення від запроваджених стандартів, а також вносити необхідні зміни щодо покращення процесної структури. Наукові дослідження й практика функціонування організацій показують, що ефективність управління бізнес-процесною структурою визначається ступенем теоретичної й методологічної обгрунтованості інноваційних нововведень та постійним їх вдосконаленням за рахунок моніторингу змін та відхилень у ході виконання бізнес-процесів.

\section{ЛIТЕРАТУРА}

1. Ареф'єва О. В. Бізнес-процеси підприємств сфери послуг: фактори, формування, конкурентноспроможність: монографія. Вид. Свропейського ун-ту, 2009. - 96с.

2. Виноградова О.В. Реінжиніринг бізнес-процесів у сучасному менеджменті: ДонДУЕТ ім. М. Туган-Барановського, 2005. - 196 с

3. Економічне обгрунтування реінжинірингу бізнес-процесів виробничих підприємств: монографія. - Суми: Мрія-1, 2010. - 440с.

4. Інформаційні технології та моделювання бізнес-процесів - Навчальний посібник (Вітер М. Б.). : Центр учбової літератури, 2010. - 186 с. 